\title{
Solar Assisted Conditioning of Residences with Floor Heating and Ceiling Cooling: Review and Simulation Results
}

\author{
A. Korkmaz ${ }^{\mathrm{a}}$ and N. Eğrican ${ }^{\mathrm{b} *}$ \\ ${ }^{a}$ Mechanical and Industrial Engineering Department, Northeastern University, Boston, MA 02115, USA \\ ${ }^{\text {bS }}$ untek International, Orhangazi Caddesi No:54/A Dragos, Kartal, Istanbul, 34865, Turkey \\ E-mail: egrican@gmail.com
}

Received 28 March 2015, Revised 18 September 2015, Accepted 22 September 2015

\begin{abstract}
Solar or solar assisted heating and cooling systems are becoming widespread to reduce $\mathrm{CO}_{2}$ emissions. Efficient radiant space heating and cooling systems can be used to decrease the energy bills and improve occupant thermal comfort in buildings. This study uses the TRNSYS program, for the modeling and simulation of solar assisted radiant heating and cooling of a building with the domestic hot water supply, to examine the effects of various parameters on energy consumption. Calculations are performed for a typical meteorological year (TMY) and ten attached houses in Istanbul, Turkey with hot water and chilled water storages on a six minute time step basis. Graphs showing variations of the room temperature and room relative humidity indicate satisfactory thermal comfort. Daily average COP of the absorption cooling system is improved by suitable choice of the type and size of the collectors. Sizes of the hot water and chilled water tanks are also important parameters; their roles are shown by their effect on the discarded portion of the heat from the collectors and the energy amount supplied by the auxiliary heater. It is concluded that the presented model for a solar assisted radiant heating and cooling of ten attached houses, with the domestic hot water supply, natural gas fueled auxiliary heater, hot water and chilled water storage tanks have considerable advantages; these should be maximized by optimizing the sizes of the solar collectors and storage tanks using a simulation program.
\end{abstract}

Keywords: Solar heating; solar cooling; chilled ceiling; absorption chiller.

\section{Introduction}

Floor heating systems are becoming increasingly popular because they may provide a more comfortable indoor thermal environment than convective heating systems. Furthermore, floor heating systems provide a good compromise between energy consumption and thermal comfort [1]. A three-dimensional explicit finite differential model was employed to determine the temperature distribution for radiant floor heating with incident nonuniform solar radiation incident. It was shown that the solar energy absorption by the thermal mass of a floor heating system might contribute to a significant reduction in energy consumption [2]. The dynamics of the three-dimensional temperature field with a direct floor heater was investigated and analyzed for the transient temperature distribution [3].

A radiant cooling system was proposed with dehumidified ventilation where the outdoor air enters the building and cools via cooling panels installed inside the building as a partition. The radiant cooling system features the cooling panels which actively lower the surface temperature to a point below the dew-point temperature, as well as raise the cooling efficiency [4]. A building equipped with a radiant cooling system can be operated in any USA climate with low risk of condensation, and can save on average $30 \%$ of the energy consumption and $27 \%$ of the peak demand due to space conditioning by employing radiant cooling system instead of the traditional all-air system [5]. Small air movement within radiant cooling systems could improve the comfortable sensation votes in radiant cooling [6]. The major concerns were discussed the radiant cooling systems, such as condensation concerns, cooling capacity concerns, and initial cost concerns compared to conventional systems $[7,8]$.

Two pairs of substances are commonly used in absorption refrigeration systems: water-lithium bromide $\left(\mathrm{LiBr}-\mathrm{H}_{2} \mathrm{O}\right)$ and ammonia-water, where the first is mainly used for solar assisted applications due to the non-toxic and non-flammable properties of water as a refrigerant [9].

According to the ECOS 2009 - World Energy Panel, world primary energy consumption grew by $1.4 \%$ in 2008 , below the 10-year average. Oil has the biggest percentage increase among the others, but usage of coal and natural gas also increased significantly. Research, development and implementation of renewable energy must continue in order to avert damage to land, water, and agriculture [10].

\section{Review}

\subsection{Solar Energy Assisted Heating and Cooling}

An absorption solar cooling system was modeled and simulated with the TRNSYS program. In this study, the optimum size of storage tank, optimum collector slope and area and optimum thermostat setting of the auxiliary boiler were found by simulation. Optimum angle is obtained as $30^{\circ}$ for the compound parabolic collector (CPC), $27^{\circ}$ for the flat plate collector and $30^{\circ}$ for the evacuated tube collector. 600 $\mathrm{L}$ hot water storage tank and $15 \mathrm{~m}^{2}$ collectors are used. The auxiliary heater set point temperature is $87^{\circ} \mathrm{C}$ for the evacuated tube collector and $\mathrm{CPC}, 84^{\circ} \mathrm{C}$ for the flat plate collector. Flat plate, evacuated and CPC collectors were compared and similar results such as boiler heat, extra heat collected and heat gain with various collector areas were 
obtained for the evacuated tube and CPC [11]. In a different study, $0.8 \mathrm{~m}^{3}$ hot water storage tank, $3.5 \mathrm{~kW}$ absorption system, $35 \mathrm{~m}^{2}$ evacuated tube collectors with $20^{\circ}$ slope were used. Boiler set point temperature was $91^{\circ} \mathrm{C}$. In this study, it was shown that with increasing sunshine, cooling load rises, and hot water storage was used to get high performance for the solar refrigeration system. In addition, daily boiler heat required decreases with increasing collector area. Conversely, daily collector energy gain increases with rising collector area [12].

A solar powered absorption cooling system was designed for $425 \mathrm{~m}^{2}$ office building with a stratified storage tank (for 2 and $\left.5 \mathrm{~m}^{3}\right)$, an absorption chiller (15 kW) and collector area between 25 and $54 \mathrm{~m}^{2}$. According to the paper, different collector area and storage volume are needed for different building orientations and locations in order to obtain high solar fraction. It is recommended to increase mass flow rate through the collectors to get steady temperature fluctuations. Doubling mass flow rate decreases the collector area and so solar thermal system costs decline by $30 \%$. Total system costs vary between 180 and $680 € \mathrm{MW} / \mathrm{h}$ with respect to the climate and control strategy [13].

A solar-powered floor heating system was designed for the building. $150 \mathrm{~m}^{2}$ evacuated tubular collectors were used in order to heat a $460 \mathrm{~m}^{2}$ area. For the heating period, the solar fraction was $56 \%$, and heating load was $25 \mathrm{~kW}$ for the building in Shanghai. Heat storage tank volume was $2.5 \mathrm{~m}^{3}$. According to the experimental results, the floor temperature varies between 20 and $24^{\circ} \mathrm{C}$ in winter. It was concluded that the performance of the system increases with increasing solar insolation rather than the ambient temperature [14].

Solar assisted air conditioning system was analyzed for an $1100 \mathrm{~m}^{2}$ building in Almería, Spain [15]. In the system, approximately $162 \mathrm{~m}^{2}$ flat plate collectors, $40 \mathrm{~kW} \mathrm{LiBr}-\mathrm{H}_{2} \mathrm{O}$ absorption chiller, cooling tower with the cooling capacity of $170 \mathrm{~kW}$, two storage tank with each $5 \mathrm{~m}^{3}$, auxiliary heater with $100 \mathrm{~kW}$ heating capacity were chosen. Coefficient of performance was approximately 0.6 . It was observed that usage of the auxiliary heater was minimized by using solar energy. In another study, solar cooling system was analyzed in Madrid, Spain [16]. In this system; $50 \mathrm{~m}^{2}$ of flat-plate collector area, $35 \mathrm{~kW}$ cooling capacity of single effect $\left(\mathrm{LiBr} / \mathrm{H}_{2} \mathrm{O}\right)$ absorption chiller and $2 \mathrm{~m}^{3}$ stratified hot water storage tank were used. Maximum cooling capacity was 7.5 $\mathrm{kW}$. COP varies between 0.3 and 0.6 . It was recommended that thicker tank insulating material should be used. Daily average collector efficiency was 0.5 . Effectiveness of the plate heat exchanger was found between 0.6 and 0.7 .

\subsection{Solar Assisted Conditioning for Comfort}

A model based control strategy for a dedicated outdoor air-chilled ceiling (DOAS-CC) system was presented with the aim of optimization of the system performance [17]. The strategy was based on simplified models such as a dehumidifier, regenerator, cooling coil, building, and genetic algorithm in order to optimize the supply air temperature and humidity of zones and the supply water temperature. The indoor air temperature and relative humidity were found as $25.3^{\circ} \mathrm{C}$ and $60 \%$ respectively. In the summer and spring, different weighting factors of cost function were used in order to find the overall cost of the entire system and $5.29 \%$ and $12.95 \%$ cost savings were achieved for the summer and spring respectively.

An overview on previous studies about the dynamic characteristics and energy performance of buildings using phase change materials (PCM) showed that thermal storage effects of PCMs have positive effects on the building thermal and energy performances and most studies are based on the simulations and experiments. On the other hand, more research for the heat transfer performance of PCM wallboards is needed, and a big temperature difference between day and night is preferred for free cooling applications [18].

A new TRNSYS type was developed and validated in order to simulate external building walls with PCM. Finitedifference method was used to solve the non-linear heat transfer problem with experimental data from their previous study for TRNSYS type. PCM material with $5 \mathrm{~mm}$ thickness and $850 \mathrm{~kg} \mathrm{~m}^{-3}$ density was chosen. Thermal conductivity of PCM varies between 0.18 and $0.22 \mathrm{~W} \mathrm{~m}^{-1} \mathrm{~K}^{-1}$. It was concluded that use of PCM inside the wall enhances the thermal inertia of buildings [19].

The thermal performance of a building roof with PCM experimentally and numerically was investigated. Thermal performance of the storage system with PCM panels with circulating water tubes has been studied. A mathematical formulation and finite volume method has been used to find the roof temperature. The effect of various PCM wall thicknesses and heat transfer coefficients has been studied. As a result, it was found that the quantity of water required for cooling is very large and calculated as $830 \mathrm{~kg} \mathrm{~m}^{-2}$ with PCM thickness between 1 and $3 \mathrm{~cm}$ [20].

A building including PCMs was simulated with TRNSYS program, and then the results were compared with the measured data [21]. The equivalent heat transfer coefficient is crucial and should be evaluated for each material. Surface control temperature with $10 \mathrm{~W} \mathrm{~m}^{-2} \mathrm{~K}^{-1}$ equivalent heat transfer coefficient is in agreement with the simulation and experiment. PCM should have a phase change temperature between $25^{\circ} \mathrm{C}$ and $27.5^{\circ} \mathrm{C}$. In addition, it is seen that surface temperature without PCM is greater than surface temperature with PCM.

The development of a thermally activated ceiling panel was described to use in lightweight and retrofitted buildings [22]. Paraffin was used as a phase change material (PCM) as its melting point range changes between $20^{\circ} \mathrm{C}$ and $24^{\circ} \mathrm{C}$ and this range can be adjusted by blending pure materials because paraffin is a by-product of petroleum distillation and combustible. The ceiling panel thickness is limited to $5 \mathrm{~cm}$ to get thermal storage capacity up to $300 \mathrm{Wh} \mathrm{m}^{-2} \mathrm{day}^{-1}$. The paper was one of the few articles which include theoretical thermal modeling of wall systems with PCM, and it is transferred to TRNSYS program. In order to increase conductivity from 0.2 to $1.2 \mathrm{~W} \mathrm{~m}^{-1} \mathrm{~K}^{-1}$, aluminum fins were used in the ceiling. Heat transfer coefficient between the room temperature and the surface temperature was $10 \mathrm{~W} \mathrm{~m}^{-}$ ${ }^{2} \mathrm{~K}^{-1}$. The room temperature remains between 21 and $28^{\circ} \mathrm{C}$ in the summer.

Usage of walls with the PCM and without the PCM was experimentally tested and compared the results with the TRNSYS simulation program [23]. It was seen from the results that there is a big difference between the outdoor and indoor temperature without the PCM. However, when the PCM was used, difference between the outdoor and indoor temperature was fairly small. Numerical simulation and experimental results are in good agreement.

Radiant ceiling panels were implemented for heating as well as cooling systems in a different study [24]. Valves were used to control the test room temperature and set according to the difference between indoor air temperature and set 
point temperature. The four ceiling water panels were connected in parallel, and a heat exchanger was used to feed the panels. The surface temperature of the ceiling panels was $19^{\circ} \mathrm{C}$, and the set point temperature of the room was $20^{\circ} \mathrm{C}$. The surface temperature of ceiling panels was held at least $17^{\circ} \mathrm{C}$ in order to avoid condensation. Then, the simulation model of the system was performed by the TRNSYS program. Coherent results were obtained between simulation and experiment in both heating and cooling season with constant heat transfer coefficients.

The main objective of this study is to develop a computational model that allows performing the simulation on an hourly basis for a heating/cooling system integrated with the absorption refrigeration system assisted by the solar energy using the TRNSYS simulation program, considering as a study region, the city of Istanbul, Turkey.

\section{System Description}

For heat supply, there are two consecutive cycles. The first cycle is for heat transfer from the flat plate and evacuated tube collectors to the heat exchanger $(\mathrm{HX})$. The fluid is a mixture of $50 \%$ water and $50 \%$ propylene, and a pump circulates it; however it is not necessary to use propylene in climates warmer than Istanbul, Turkey [25]. There are 18 parallel collector sets consisting of a flat plate and an evacuated tube collector connected to each other in the series. The 2 nd cycle transfers heat from the cold side of the HX to the storage. An auxiliary heater (AUX) with a pump, parallel to the HX circuit is used to supply energy to the storage tank using natural gas whenever there is not enough solar radiation. The set point temperature of AUX is set to $90^{\circ} \mathrm{C}$. Therefore, when the water comes from the hot storage tank (HST) at $90^{\circ} \mathrm{C}$ or higher, AUX does not work. If the temperature of the water is less than $90^{\circ} \mathrm{C}$, AUX starts working. Then, the water is carried to the storage tank by the pipes. HST is a regular insulated tank and there is neither auxiliary heater nor a thermostat element used inside it. After the AUX, the flow is diverted into two in order to separate the flow for the domestic hot water (DHW) and rest of the system. For the DHW part, mass flow rate is divided by 10 before the controllable valve due to the fact that there are 10 consecutive buildings and multiplied by 10 after combining the flows to make simulation fast as shown in Figure 1. Similarly, mass flow rate at 9 and 13 are divided by 10 and mass flow rate at 10 and 14 in Figure 1 are multiplied by 10 . The city water is heated while passing through the HX. The flow is separated again with respect to the heating and cooling season.

Heating of the house is performed by using an active layer on the floor. The house has six zones, and each zone has a different size of radiant floor due to their different floor areas and heat capacity. Hot flow rate for each zone is distributed according to the air temperature of each zone.

The hot water that comes from the HST is diverted into six parts by the diverting valve. Then, it is transmitted to another valve that is controlled by the feedback controllers in order to set the temperature in the specified values. In addition, in order to set the room temperatures in a certain interval; fluid with different amounts exits the diverting valve at the specified outlet port according to the need. The sum of the fractions must be equal to one in the diverting valve to conserve the mass flow rate. There are six ports with respect to the number of zones.
There are three cycles of the absorption chiller (AC), and these are cooling water, chilled water, and hot water, respectively. The cooling water flows between the cooling tower and the $\mathrm{AC}$ in the 3rd cycle. Chilled water goes from the AC to the cold storage tank (CST), and then it is distributed to the chilled ceiling of each zone by the pump in the 4th cycle. The hot water flow starts from the HST goes through the AUX and diverting valves, reaches the AC in the 5 th cycle as shown in Figure 1. For each cycle, pumps are used and turned on/off by the controller. This controller takes the input signal from the CST and gives the output signal to the pumps in the AC cycles.

For heating, the active layer is used as shown in Figure 2a and the indoor temperature feedback controller is used so that the radiant floor system can respond to the internal load changes. The chilled ceiling panels are used as shown in Figure $2 b$ for the cooling in summer. The indoor temperature feedback control is used in order to control the mass flow rate to the zones. If the indoor temperature is higher than the set point temperature, then the supply flow rate is increased. However, if the indoor temperature is lower than the set point temperature, the supply flow rate is decreased by the controllers.

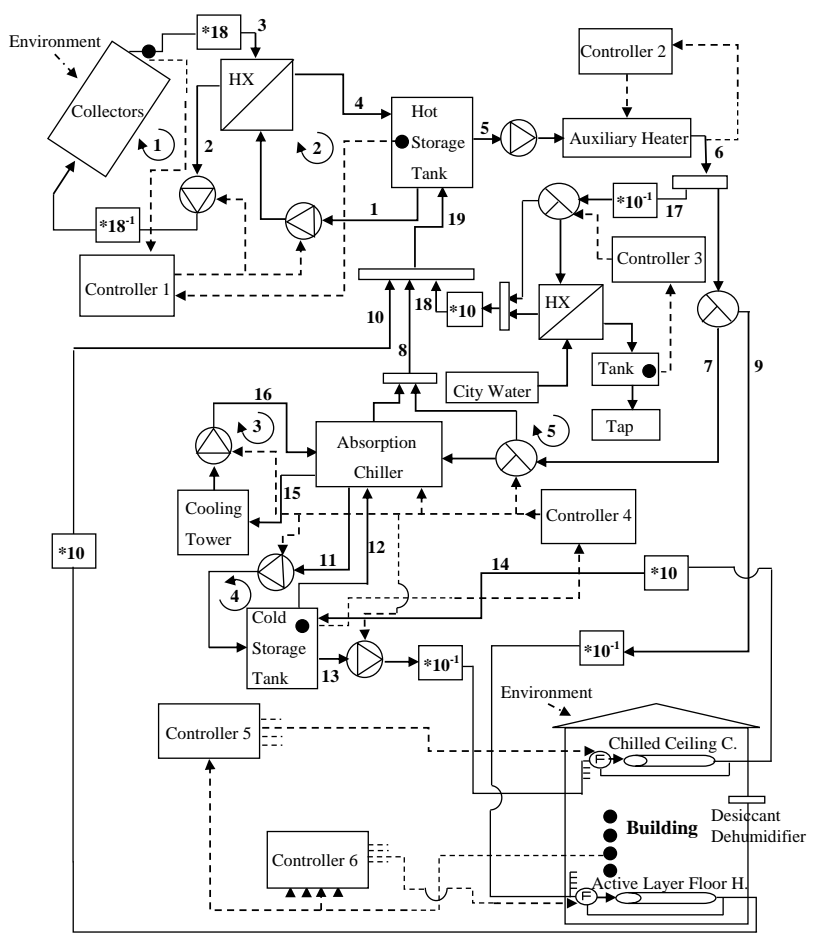

Figure 1. Schematic of solar assisted heating and cooling system. a)

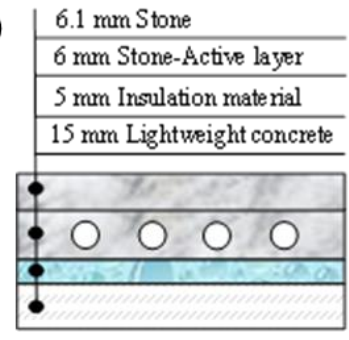

b)

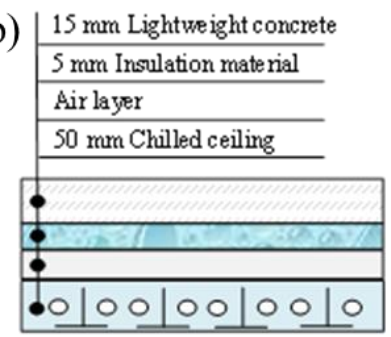

Figure 2. Layers of a) the floor, b) the chilled ceiling. 


\section{Description of the Computational Simulation}

The thermal performance and control characteristics of the proposed heating and cooling system are evaluated using TRNSYS (Transient System Simulation Program) for a housing unit in an apartment building located in Istanbul, Turkey. This simulation program is based on the transfer function method capable of dynamic simulations [26]. To model the thermal behavior of a building divided into the different thermal zones, multi-zone building module (Type 56 ) is used in this study. Each simulated house is $3 \mathrm{~m}$ high and has approximately $120 \mathrm{~m}^{2}$ of floor area, and there are ten attached houses. All of the external walls are identical except the walls between houses, which are insulated highly to minimize heat transfer between houses. The house has six rooms as shown in Figure 3. All of the rooms are included in calculations of heating and cooling except the entrance, which is not conditioned. The values of the total thickness and overall heat transfer coefficients for different walls are given in Table 1.

Table 1. Total Thicknesses and the Overall Heat Transfer Coefficients (U) for Different Wall Types.

\begin{tabular}{lll}
\hline Wall Type & Total Thickness $(\mathrm{m})$ & $U\left(\mathrm{~W} / \mathrm{m}^{-2} \mathrm{~K}^{-1}\right)$ \\
\hline Ceiling & 0.200 & 0.642 \\
Outer & 0.125 & 0.491 \\
Inner & 0.100 & 1.456 \\
Floor & 0.321 & 0.599 \\
\hline
\end{tabular}

In the TRNSYS simulation program, weather data is used to give the required inputs for the solar collector, psychometrics, house, etc. The evacuated tube collector takes the solar zenith, azimuth angle and the radiations from the weather and gives energy as an output to the waterpropylene mixture with $50 \%$. The sky temperature takes the beam radiation and sky diffuse radiation as an input to give the fictive sky temperature for the house.

The solar gain from the collector is transmitted to the working fluid, water-propylene mixture. For this cycle, the mass flow rate is $19998 \mathrm{~kg} \mathrm{~h}^{-1}$. The fluid specific heat is 3.64 $\mathrm{kJ} \mathrm{kg}^{-1} \mathrm{~K}^{-1}$. The total area of collectors is $540 \mathrm{~m}^{2}$.

At the 2nd cycle, as shown in Figure 3, the total mass flow rate is $17373 \mathrm{~kg} \mathrm{~h}^{-1}$. After the pipe 4 , the working fluid goes into the AUX to heat the fluid if there is not enough solar radiation. The set point temperature is $90^{\circ} \mathrm{C}$. That means, if the inlet temperature to the AUX is less than $90^{\circ} \mathrm{C}$, it will be activated. Otherwise, it will be non-active. The maximum heating rate is $300 \mathrm{MJ} \mathrm{h}^{-1}$. For the AUX, natural gas is used, and the thermal conversion efficiency of the AUX is 0.79 . At the end of the 2nd cycle, the working fluid goes into the thermal storage. Six temperature levels are used in the tank. The tank loss coefficient is $0.0008 \mathrm{~kJ} \mathrm{~h}^{-1} \mathrm{~m}^{-2} \mathrm{~K}^{-1}$, and the volume of HST is $45 \mathrm{~m}^{3}$.

After the thermal storage, hot water is transmitted by the pump 3 to the heating and cooling parts. The mass flow rate is $6000 \mathrm{~kg} \mathrm{~h}^{-1}$. After pump 3, the hot water comes to the diverter to separate the flow for the domestic hot water and the rest of the system. For the DHW part, the HX was used in order to heat the city water with a flow rate of $25 \mathrm{~kg} \mathrm{~h}^{-1}$ for four people and the flow rate of the hot side of the HX is controlled by the controller in order to obtain the DHW in a certain temperature. The temperature of the city water is $15^{\circ} \mathrm{C}$ in the winter and $20^{\circ} \mathrm{C}$ in the summer.

After the diverter 2, the hot water is separated into two channels, one for the mixer and the other for another diverter to send the water to the single effect hot water fired AC according to the need. If there is no need to cool the zones, the hot water will not enter the absorption chiller. The flow is controlled by the time controller according to the season. In order to set the flow of the working fluid for the winter and summer, this equation is added to the control signal of the separator. By using this equation, hot water is sent to the AC from 2520 to 6552 hours. Except for these hours, hot water will go to the mixing valve directly. In order to combine the diverter to $\mathrm{AC}$, the outlet temperature is connected to the hot water inlet temperature, and the outlet flow rate is connected to the hot water flow rate. The hot water flow rate is connected to the mixing valve to complete the cycle. The mass flow rate of hot water in the AC is 2436 $\mathrm{kg} \mathrm{h}^{-1}$. For the AC, the rated capacity is $108000 \mathrm{~kJ} \mathrm{~h}^{-1}$. COP is 0.53 as a parameter for $30^{\circ} \mathrm{C}$ inlet cooling temperature and $7^{\circ} \mathrm{C}$ chilled water temperature. The cooling water of the absorption chiller is connected to the cooling tower, the outputs are connected to the $\mathrm{AC}$ to complete the cycle, and a pump is used to circulate the water in the cycle. The mass flow rate of the cooling water in the AC is $11385 \mathrm{~kg} \mathrm{~h}^{-1}$. There are two cycles for the CST. The chilled water goes from the AC to the tank from the bottom, and the heated water comes from the top part of the tank to the AC. The cooled water goes to the building by the diverters that are controlled by the feedback controllers with respect to the zone temperature. The heated water by the building comes back to the CST from the top level. The mass flow rate of the chilled water is $5205 \mathrm{~kg} \mathrm{~h}^{-1}$. The same control signal is also applied to the AC and the pumps for the cooling and chilled water cycles and diverter 3 . The control signal is given according to the outlet temperature of the flow from the CST. When the outlet temperature of the chilled water exceeds $20^{\circ} \mathrm{C}$, the $\mathrm{AC}$ becomes active and if the outlet temperature is lower than $16^{\circ} \mathrm{C}$, the $\mathrm{AC}$ is closed and the hot water does not enter the $\mathrm{AC}$. 


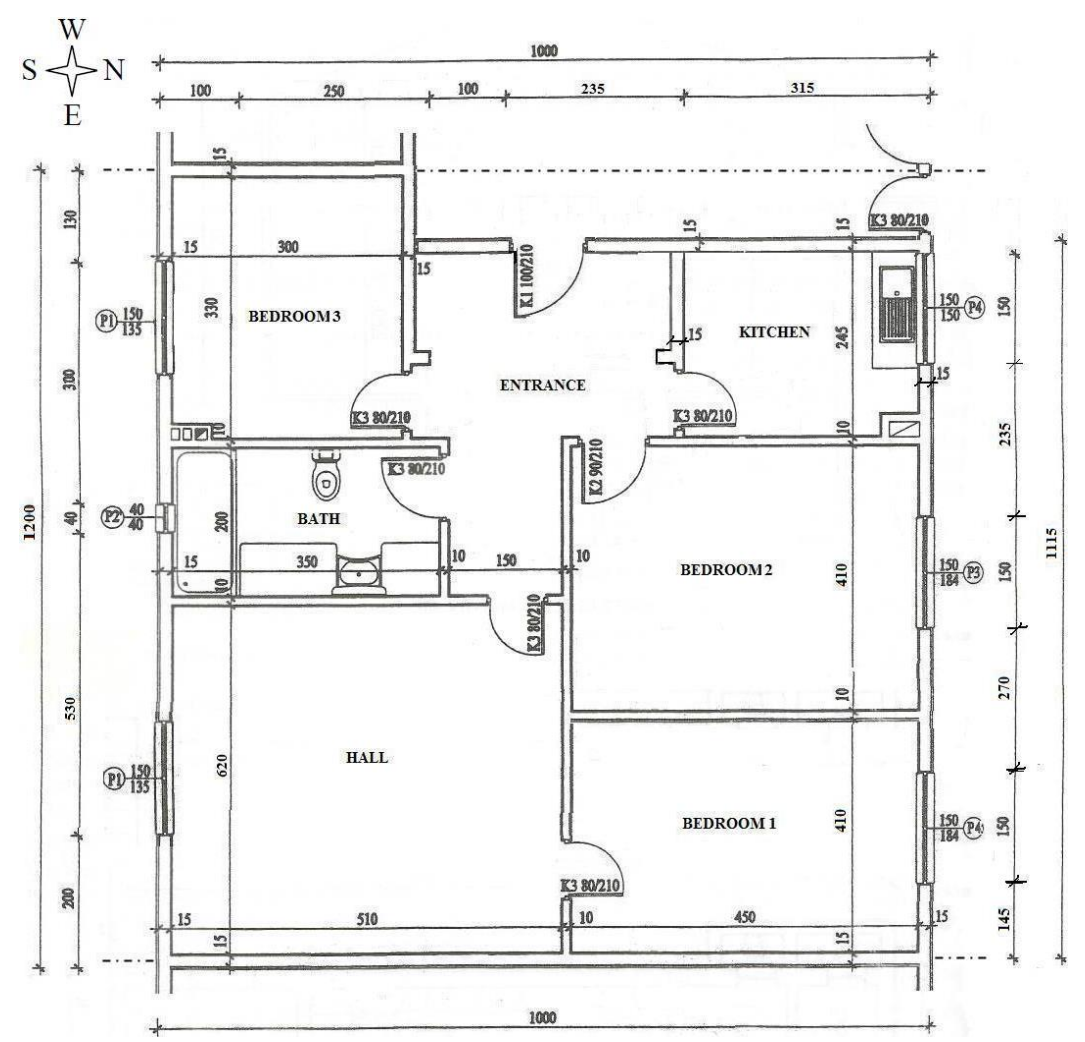

Figure 3. The plan of the house.

After the mixing valve, the working fluid goes into the diverting valve to divide the flow to each zone. To combine the mixing and diverting valve, the outlet temperature of the mixing valve is connected to the inlet temperature of the diverting valve and the outlet flow rate of the mixing valve is connected to the inlet flow rate of the diverting valve. For the diverting valve, the number of outlet ports is taken as six, which is equal to the heated or cooled zone number.

After the diverting valve, the working fluid, water, goes to the controlled flow diverters for the each panel of the zones throughout the year. Controlling occurs with respect to the desired temperature of the zones. For the heating season, controlling temperature is $20^{\circ} \mathrm{C}$ and below this temperature, the water is sent to the zones through the valves. For the cooling season, the set point temperature is $22^{\circ} \mathrm{C}$. If the room temperature is higher than $22^{\circ} \mathrm{C}$, the cold water is sent to the zone through the valves. The controller is modeled in the TRNSYS as a feedback controller, and separate controllers are used for each zone. The feedback controller senses temperature of the zone and it controls the flow of diverters. For example, if the room temperature is under the set point value in winter, the diverter is opened by the feedback controller and the hot water coming from the storage tank is transmitted to the active layer. The chilled water that comes from the AC is moved to the controlled diverter and it is turned on/off according to the set point temperature of the zones in order to make comfort conditions between 2520 and 6552 hours. For each zone, separate radiant floor and diverter are used. The building is assumed to be used all the time. However, the lighting is just used between 18:00 and 24:00. The radiative power is $1500 \mathrm{~kJ} \mathrm{~h}^{-1}$, and the convective power is $300 \mathrm{~kJ} \mathrm{~h}^{-1}$ for the lighting and four people occupy it. In each bedroom, one person is placed according to the ISO 7730 with seated, light work and typing. One person placed in the kitchen according to the ISO 7730 with seated and eating. One computer is added to the hall with $230 \mathrm{~W}$. The TRNSYS model of all the system is shown in Figure 4.

The following TRNSYS component models (Types) were used in the simulation:

Type 56, Multi-zone modeling;

Type 109, Data reader and radiation processor;

Type 71, Evacuated tube collector;

Type 33, Psychrometrics: dry bulb and relative humidity known;

Type 709, Circular: fluid-filled pipe;

Type 69, Effective sky temperature for long-wave radiation exchange;

Type 114, Single speed pump;

Type 5b, Heat exchanger;

Type 6, Auxiliary heater;

Type 4a, Stratified storage tank with uniform losses;

Type 14e, Time dependent forcing function: temperature;

Type 11f, Controlled flow diverter;

Type 11d, Controlled flow mixer;

Type 647, Fluid diverting valve with up to 100 outlets;

Type 22, Iterative feedback controller;

Type 60d, Storage tank; fixed inlets, uniform losses;

Type 51b, Cooling tower: User-supplied performance coefficients;

Type 649, Mixing valve for fluids with up to 100 inlets; Type 680, Hot water-fired single-effect absorption chiller; Type 14b, Time dependent forcing function: water draw; Type 60c, Storage tank; fixed inlets, uniform losses and node heights;

Type 60d, Storage tank; fixed inlets, uniform losses and node heights;

Type 24, Quantity integrator;

Type 65d, Online graphical plotter with the output file;

Type 25a, Printer - TRNSYS-supplied units printed to the output file;

Type 77, Soil temperature profile. 


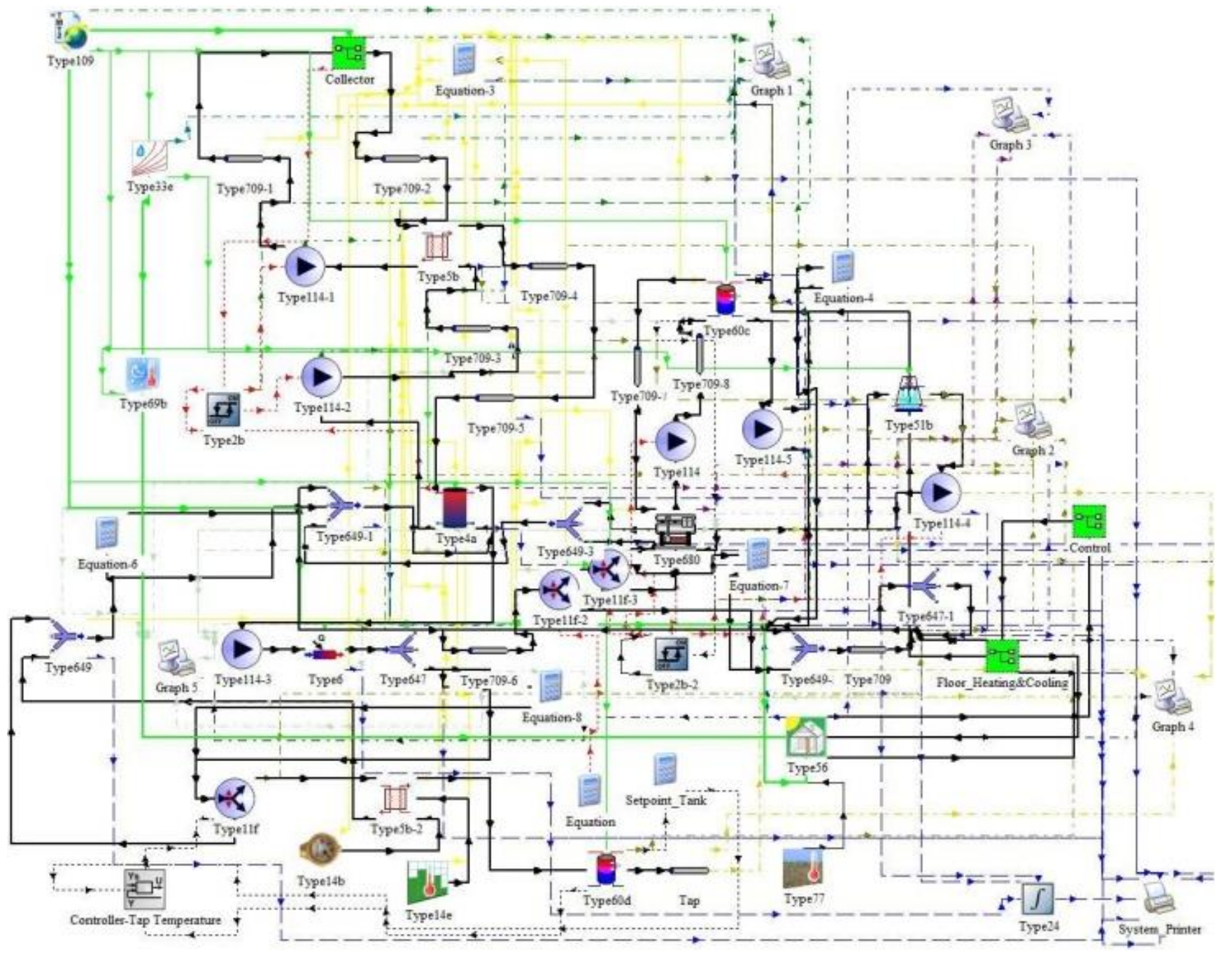

Figure 4. TRNSYS model of the complete system.

\section{Simulation and Result}

Simulation of the above system is performed for a building consisting of ten attached houses located in Istanbul, Turkey. To investigate the thermal performance of the system long term, a database for a Typical Meteorological Year (TMY) in the locality under study is needed. In this work, the climate database is built using the information provided by the meteorological data of Istanbul, Turkey at the TRNSYS. In order to eliminate the initialization period during the simulation process, $96 \mathrm{~h}$ simulation with six minute time steps was performed, and the result of the last day was presented in the following figures.

First of all, the fuel consumption of the AUX with different set point temperature for one day is shown in Figure 5. The gas consumption increases $9.56 \%$ while rising set point temperature $1^{\circ} \mathrm{C}$.

The fuel consumption of the AUX can be divided into two regions according to the changing volume. In the 1st region, the fuel consumption is dramatically decreasing with the increasing HST volume from 16 to $35 \mathrm{~m}^{3}$, and $1 \mathrm{~m}^{3}$ volume increase results in $3.96 \%$ decrease in the energy usage. In the second region, there is a slight decrease in the energy consumption between 35 and $55 \mathrm{~m}^{3}$ as shown in Figure 6 and $1 \mathrm{~m}^{3}$ volume increase results in $1.81 \%$ decrease in the energy usage. These results show that HST volume less than $35 \mathrm{~m}^{3}$ is not sufficient for the whole system.

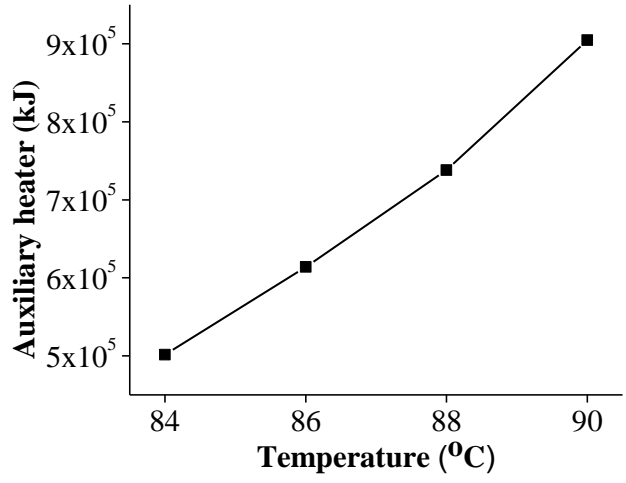

Figure 5. Fuel consumption of the AUX versus set point temperature of the AUX on August 14. 


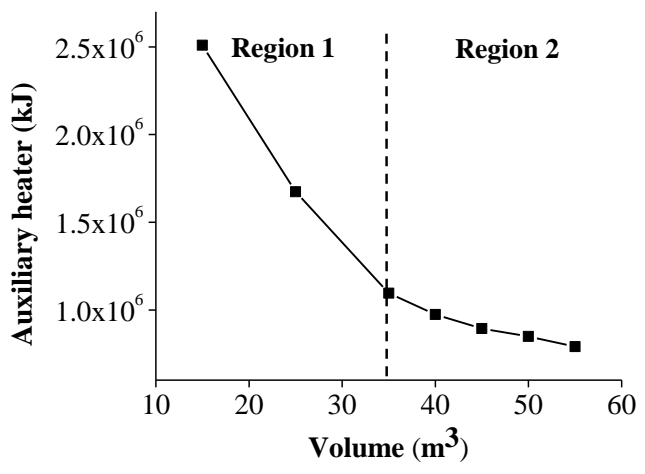

Figure 6. Fuel consumption of the AUX versus volume of the HST on August 14.

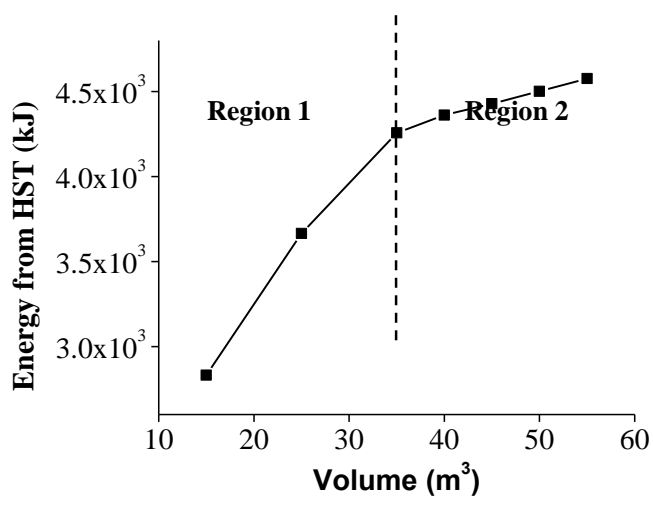

Figure 7. Energy from the HST versus volume of the HST on August 14.

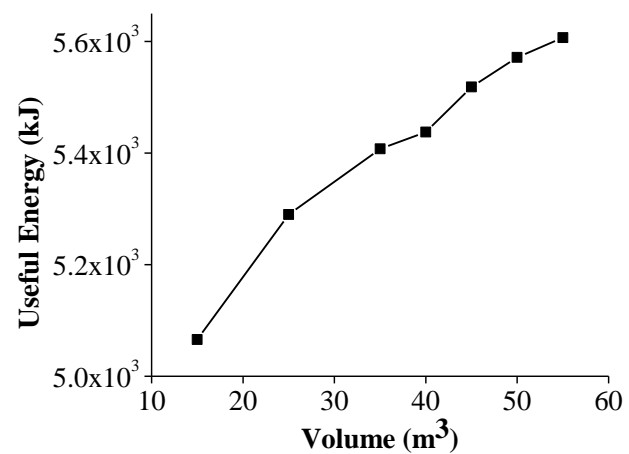

Figure 8. Energy gain from the collectors versus volume of the HST on August 14.

Energy delivery from the HST to the system can be divided into two parts. In the 1st part, the energy delivery from the HST is significantly increasing from 15 to $35 \mathrm{~m}^{3}$ due to the insufficient tank volume as shown in Figure 7 and $1 \mathrm{~m}^{3}$ increase corresponds to $2 \%$ rise in the energy gain from the HST. After $35 \mathrm{~m}^{3}$, the system reaches its saturation level, $1 \mathrm{~m}^{3}$ increases corresponds to $0.09 \%$ rise in the energy gain from the HST. The energy gain from the collectors according to the changing HST volume is shown in Figure 8. The daily auxiliary heater usage with the changing CST volume is shown in Figure 9.

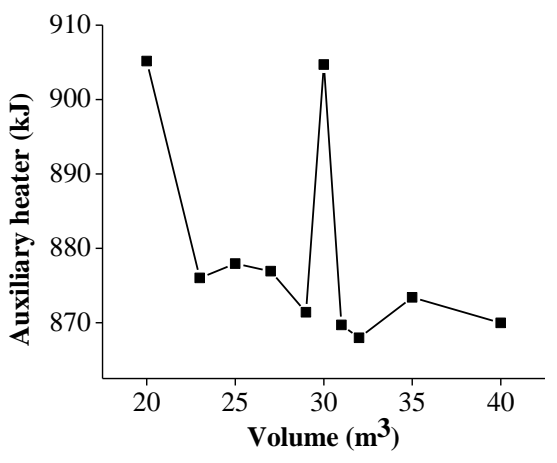

Figure 9. Energy consumption by the AUX versus volume of the CST on August 14.

Energy consumption by the AUX with different chilled water set point temperature is shown in Figure 10. It is seen from the figure that the fuel consumption decreases with increasing temperature and $1^{\circ} \mathrm{C}$ rise in set point temperature corresponds to $3.21 \%$ decrease in the gas consumption. However, in order to prevent condensation on the walls and to satisfy thermal comfort, $17^{\circ} \mathrm{C}$ is chosen for the chilled water set point temperature at the rest of the paper.

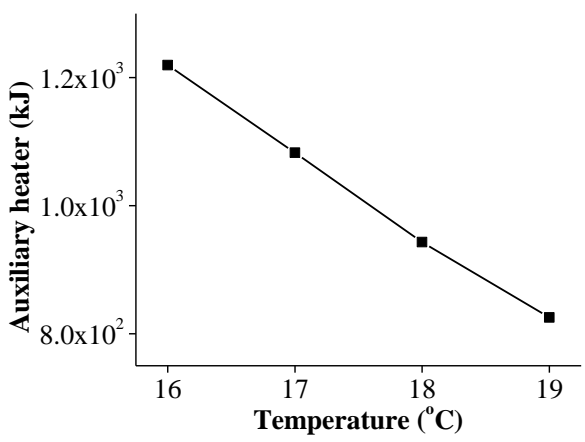

Figure 10. Energy consumption by the AUX versus set point temperature of the chilled water on August 14.

Energy consumption by the AUX is decreasing with increasing collector area as illustrated in Figure $11\left(1 \mathrm{~m}^{2}\right.$ rise corresponds to $0.34 \%$ decrease). In addition, the useful energy collected by the collector rises with increasing collector area as seen from Figure 12 and $1 \mathrm{~m}^{2}$ rise correspond to $0.12 \%$ increase in the useful energy gain.

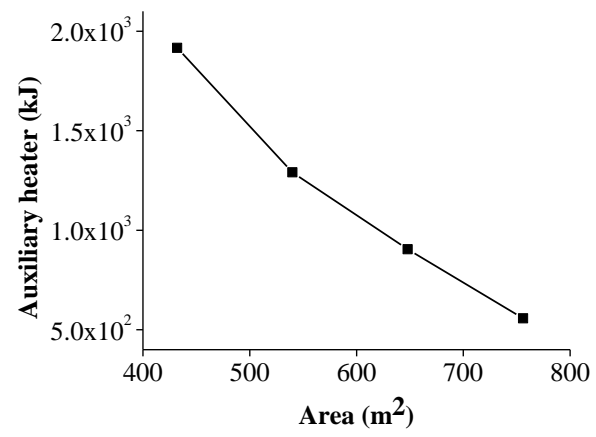

Figure 11. Energy consumption by the AUX versus collector area on August 14. 


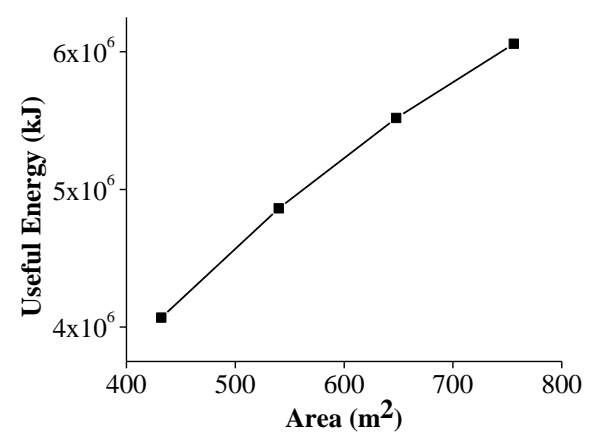

Figure 12. Energy gain by the collectors versus collector area on August 14.

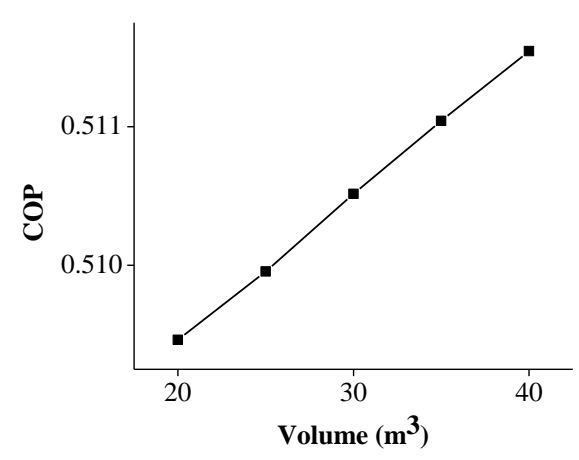

Figure 13. COP versus volume of the CST between April 16 and October 1.

Coefficient of performance (COP) of the absorption chiller increases slightly with rising CST volume as shown in Figure 13. Fuel consumption of the AUX increases a bit between 20 and $30 \mathrm{~m}^{3}$, decreases slightly between 30 and 40 $\mathrm{m}^{3}$ as shown in Figure 14 .

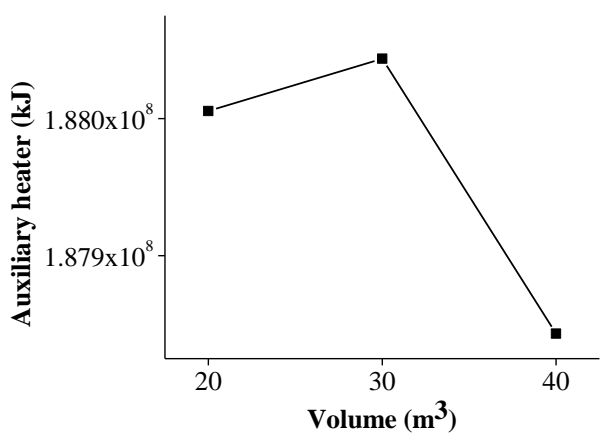

Figure 14. Energy consumption of the AUX versus volume of the CST between April 16 and October 1.

In order to control the pumps between the collector and $\mathrm{HX}$, the pumps between the HX and HST, a comparison is made between the collector and HST outlet temperature. The pumps are opened when the temperature difference is $10^{\circ} \mathrm{C}$; the pumps are stopped when the temperature difference is $2^{\circ} \mathrm{C}$ as shown in Figure 15. Fluctuation in the collector temperature depends on the variation of the total horizontal radiation amount.

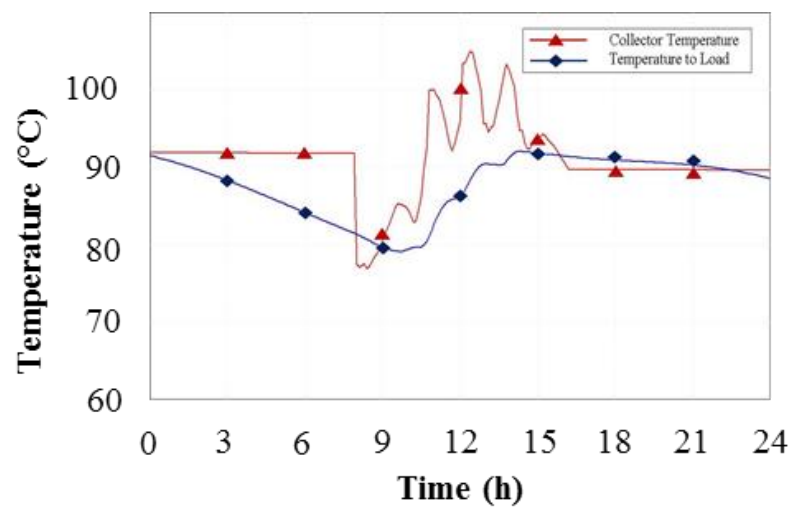

Figure 15. Collector outlet and the HST temperature on August 14.

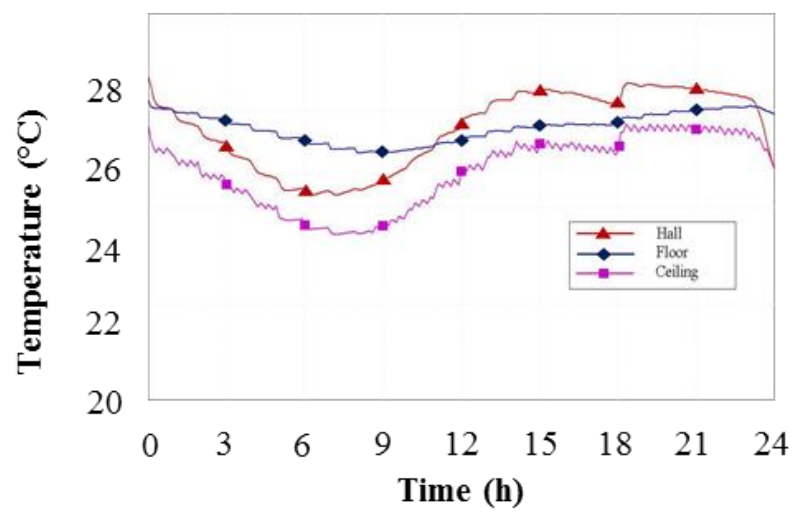

Figure 16. Indoor air, floor and the chilled ceiling surface temperature of the hall on August 14.

Indoor air temperature of the zones is held in certain values to provide thermal comfort. The hall indoor temperature, floor temperature, and ceiling temperature are shown in Figure 16. The hall indoor temperature changes between 22 and $28^{\circ} \mathrm{C}$ through the summer. It is shown that hall has the biggest cooling capacity among all of the zones. The temperature difference between the floor and ceiling is always less than $5^{\circ} \mathrm{C}$ during all the year.

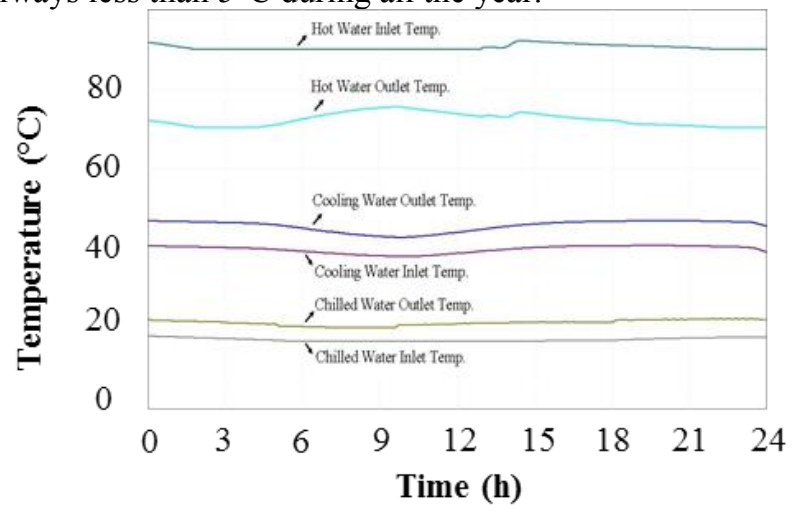

Figure 17. Outlet and inlet temperature of the cycles through the AC on August 14.

Outlet and inlet temperatures of the three cycles through the AC on August 14 are shown in Figure 17. It is shown in Figure 18 that the dew point temperature is lower than the chilled ceiling surface temperature, and there is always a temperature difference between the chilled ceiling surface temperature and the dew point temperature during the cooling season. As a result, there is no condensation problem on the walls. 
Table 2. Simulated Temperature Values in $\left({ }^{\circ} \mathrm{C}\right)$ for All the System Except Points 9 and 10 with 6 Minutes Time-steps on August 14.

\begin{tabular}{llllllllllllllllll}
\hline Time & T1 & T2 & T3 & T4 & T5 & T6 & T7 & T8 & T11 & T12 & T13 & T14 & T15 & T16 & T17 & T18 & T19 \\
\hline 00:00 & 73.8 & 91.9 & 91.9 & 91.4 & 91.6 & 91.6 & 91.8 & 72.3 & 18.3 & 22.8 & 18.0 & 22.9 & 47.2 & 40.9 & 91.6 & 68.0 & 71.5 \\
03:00 & 71.5 & 91.9 & 91.9 & 91.4 & 88.4 & 90.0 & 90.0 & 70.4 & 17.7 & 22.2 & 18.0 & 21.7 & 46.7 & 40.5 & 90.0 & 68.8 & 70.2 \\
06:00 & 71.0 & 91.9 & 91.9 & 91.3 & 84.2 & 90.0 & 90.0 & 72.7 & 17.0 & 21.4 & 17.5 & 20.7 & 45.3 & 39.5 & 90.0 & 68.8 & 72.0 \\
09:00 & 73.6 & 75.9 & 80.5 & 76.9 & 79.7 & 90.0 & 90.0 & 75.4 & 17.0 & 20.7 & 17.1 & 20.5 & 43.2 & 38.4 & 90.0 & 66.3 & 73.9 \\
12:00 & 78.6 & 85.0 & 96.0 & 87.6 & 86.1 & 90.0 & 90.0 & 73.9 & 17.0 & 21.1 & 17.1 & 21.5 & 44.3 & 39.1 & 90.0 & 66.3 & 72.6 \\
15:00 & 86.6 & 89.2 & 93.5 & 90.3 & 91.9 & 91.9 & 92.0 & 74.0 & 17.1 & 21.6 & 17.1 & 21.9 & 46.4 & 40.5 & 91.9 & 72.3 & 73.7 \\
18:00 & 79.8 & 89.7 & 89.7 & 89.1 & 90.9 & 91.0 & 91.1 & 72.2 & 17.3 & 21.8 & 17.3 & 21.9 & 47.0 & 40.9 & 91.0 & 69.6 & 71.8 \\
21:00 & 73.6 & 89.7 & 89.7 & 89.1 & 90.3 & 90.4 & 90.5 & 70.9 & 17.9 & 22.3 & 17.6 & 22.6 & 47.1 & 40.9 & 90.4 & 71.2 & 71.0 \\
24:00 & 71.2 & 89.7 & 89.7 & 89.0 & 88.6 & 90.0 & 90.0 & 70.4 & 18.1 & 22.6 & 18.0 & 22.4 & 45.8 & 39.4 & 90.0 & 70.9 & 70.5 \\
\hline
\end{tabular}

Table 3.Simulated Temperature Values in $\left({ }^{\circ} \mathrm{C}\right)$ for All the System Except Points 7, 8 and 11-16 with 6 Minutes Time-steps on January 8.

\begin{tabular}{llllllllllll}
\hline Time & T1 & T2 & T3 & T4 & T5 & T6 & T9 & T10 & T17 & T18 & T19 \\
\hline $00: 00$ & 48.3 & 48.4 & 48.4 & 46.9 & 48.3 & 50.0 & 50.0 & 50.0 & 50.0 & 38.2 & 49.0 \\
$03: 00$ & 44.7 & 48.3 & 48.3 & 46.9 & 48.3 & 50.0 & 50.0 & 44.3 & 50.0 & 38.2 & 43.8 \\
$06: 00$ & 43.2 & 48.3 & 48.3 & 46.8 & 47.3 & 50.0 & 50.0 & 43.6 & 50.0 & 38.2 & 43.2 \\
$09: 00$ & 43.5 & 48.3 & 48.3 & 46.8 & 45.3 & 50.0 & 50.0 & 45.1 & 50.0 & 38.2 & 43.8 \\
$12: 00$ & 45.9 & 50.7 & 57.7 & 52.6 & 48.2 & 50.0 & 50.0 & 49.6 & 50.0 & 38.2 & 48.6 \\
$15: 00$ & 52.1 & 53.9 & 57.5 & 54.8 & 55.3 & 55.3 & 55.7 & 55.2 & 55.3 & 41.7 & 54.1 \\
$18: 00$ & 53.4 & 55.2 & 55.2 & 54.6 & 54.8 & 54.8 & 54.9 & 54.5 & 54.8 & 41.4 & 53.4 \\
$21: 00$ & 53.3 & 55.1 & 55.1 & 54.6 & 54.0 & 54.0 & 54.1 & 54.1 & 54.0 & 40.8 & 53.0 \\
$24: 00$ & 52.7 & 55.1 & 55.1 & 54.6 & 53.6 & 53.6 & 53.7 & 53.7 & 53.6 & 40.6 & 52.6 \\
\hline
\end{tabular}

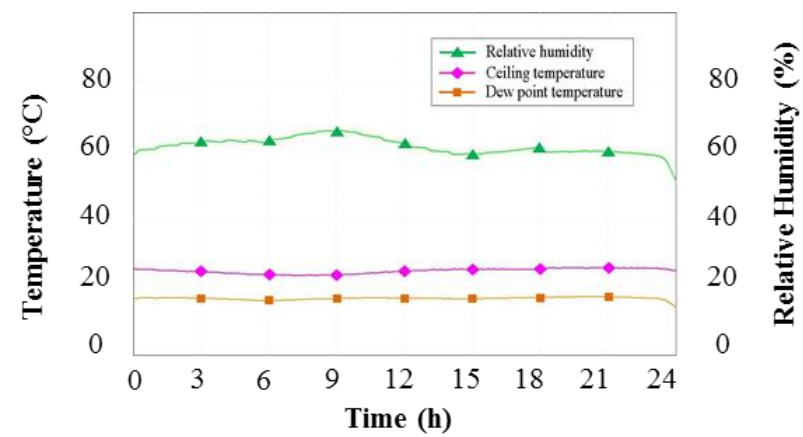

Figure 18. Relative humidity, chilled ceiling surface temperature and the dew point temperature of the hall on August 14.

During the heating season, indoor temperature of the hall varies between 18 and $24^{\circ} \mathrm{C}$. The floor surface temperature and indoor temperature of the hall are shown in Figure 19 on January 8.

For the entire system as shown in Figure 3, the temperature values at each point for a day in the summer season are shown in Table 2 . The points 9 and 10 are not put into the table because there is no flow in these points during the cooling season. Similar data for a day in the winter season are shown in Table 3 . The rest of the points are not put into the table because there is no flow in those points during the heating season.

\section{Conclusions}

In this study, DHW supply, heating, cooling and controlling of a building consisting of ten attached multizone houses with six zones in Istanbul, Turkey were investigated and simulated in TRNSYS 17. The thermal comfort conditions of the house were provided throughout the whole year by using floor heating with an active layer and cooling with a chilled ceiling. The condensation problem during the summer season is solved by setting the chilled water temperature from the $\mathrm{AC}$ to $17^{\circ} \mathrm{C}$ since temperatures below this point result in condensation on the walls.

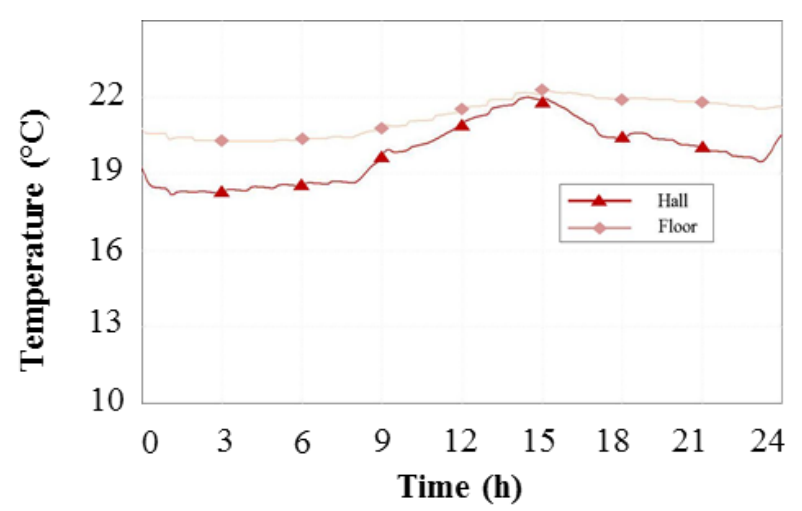

Figure 19. Indoor hall and the floor surface temperature on January 8.

As a renewable energy source, the solar energy has been used by the flat plate and evacuated tube collectors. The total area of the buildings in the simulation is $1200 \mathrm{~m}^{2}$, collectors are with $540 \mathrm{~m}^{2}$, HST is with $45 \mathrm{~m}^{3}$ and CST is $30 \mathrm{~m}^{3}$. The temperature of the working fluid can reach up to $110^{\circ} \mathrm{C}$ due to the high solar radiation, depending on the collector surface area. The solar gain changes according to the solar radiation. With the increasing collector area, useful energy from the sun increases and added energy from the AUX decreases. Added energy from the AUX to the water changes with the weather conditions. It is seen from the results that there is an optimum volume for both the HST and CST. The temperature of the DHW is held at the desired value between $40^{\circ} \mathrm{C}$ and $60^{\circ} \mathrm{C}$ by using the feedback controller with the aid of the solar energy and AUX. It is concluded from this study that it is possible to obtain good indoor thermal conditions by using active layer floor heating and chilled ceiling together. Using this comprehensive model of simulation for ten consecutive multi-zone building in Istanbul, Turkey, the 
temperature of each zone is held between 18 and $28^{\circ} \mathrm{C}$ throughout the year.

As a future work, the thermal efficiency of each component, the cycles and cost optimization of this work would be worth investigating in detail.

\section{Acknowledgements}

The authors would like to thank to Dr. Yalçın A. Göğüş for his help and comments on this project.

\section{References}

[1] C. Inard, A. Meslem, P. Depecker, "Energy consumption and thermal comfort in dwelling-cells: a zonal-model approach,' Build. Environ., 33, 279-291, 1998.

[2] A.K. Athienitis, Y. Chen, "The effect of solar radiation on dynamic thermal performance of floor heating systems,' Solar Energy, 69, 229-237, 2000.

[3] J. Golebiowski, S. Kwieckowski, "Dynamics of threedimensional temperature field in electrical system of floor heating,', Int J Heat Mass Tran, 45, 2611-2622, 2002.

[4] D. Song, T. Kim, S. Song, S. Hwang, S. B. Leigh, "Performance evaluation of a radiant floor cooling system integrated with dehumidified ventilation," Applied Thermal Eng., 28, 1299-1311, 2008.

[5] S. Corina, "Energy and peak power saving potential of radiant cooling systems in US commercial buildings,' Energy Buildings, 30, 127-138, 1999.

[6] K. Kitagawa, N. Komoda, H. Hayano, S. I. Tanabe, "Effect of humidity and small air movement on thermal comfort under a radiant cooling ceiling by subjective experiments,' Energy Buildings, 30, 185-193, 1999.

[7] S. A. Mumma, C. L. Conroy, "Ceiling radiant cooling panels as a viable distributed parallel sensible cooling technology integrated with dedicated outdoor air systems,"' ASHRAE Transactions, 107, 578-585, 2001.

[8] S. A. Mumma, "Chilled ceiling in parallel with dedicated outdoor air systems: addressing the concerns of condensation, capacity, and cost," ASHRAE Transactions, 108, 220-231, 2002.

[9] H. Vidal, R. Escobar, S. Colle, "Simulation and optimization of a solar driven air conditioning system for a house in Chile," Proceedings of the ISES Solar World Congress, pp. 844-853, 2009.

[10] N. Lior, "The ECOS 2009 World Energy Panel: An introduction to the panel and to the present (2009) situation in sustainable energy development," Energy, 36, 3620-3628, 2011.

[11] G. A. Florides, S. A. Kalogirou, S. A. Tassou, L. C. Wrobel, "Modelling, simulation and warming impact assessment of a domestic-size absorption solar cooling system,' Applied Thermal Eng., 22, 1313-1325, 2002.

[12] F. Assilzadeh, S. A. Kalogirou, Y. Ali, K. Sopian, "Simulation and optimization of a LiBr solar absorption cooling system with evacuated tube collectors," Renewable Energy, 30, 1143-1159, 2005.

[13] U. Eicker, D. Pietruschka, "Design and performance of solar powered absorption cooling systems in office buildings,' Energy Buildings, 41, 81-91, 2009.
[14] X. Q. Zhai, J. R. Yang, R. Z. Wang, “Design and performance of the solar-powered floor heating system in a green building,' Renewable Energy, 34, 17001708, 2009.

[15] S. Rosiek, F. J. Batlles, "Integration of the solar thermal energy in the construction: Analysis of the solarassisted air-conditioning system installed in CIESOL building," Renewable Energy, 34, 1423-1431, 2009.

[16] A. Syed, M. Izquierdo, P. Rodríguez, G. Maidment, J. Missenden, A. Lecuona, R. Tozer, "A novel experimental investigation of a solar cooling system in Madrid,', Int. J. Refrigeration, 28, 859-871, 2005.

[17] G. Ge, F. Xiao, X. Xu, “'Model-based optimal control of a dedicated outdoor air-chilled ceiling system using liquid desiccant and membrane-based total heat recovery,' Applied Energy, 88, 4180-4190, 2011.

[18] N. Zhu, Z. Ma, S. Wang, "Dynamic characteristics and energy performance of buildings using phase change materials: A review,' Energy Convers. Management, 50, 3169-3181, 2009.

[19] F. Kuznik, J. Virgone, K. Johannes, “'Development and validation of a new TRNSYS type for the simulation of external building walls containing PCM," Energy Buildings, 42, 1004-1009, 2010.

[20] A. Pasupathy, L. Athanasius, R. Velraj, R. V. Seeniraj, "Experimental investigation and numerical simulation analysis on the thermal performance of a building roof incorporating phase change material (PCM) for thermal management," Applied Thermal Eng., 28, 556-565, 2008.

[21] M. Ibáñez, A. Lázaro, B. Zalba, L. F. Cabeza, “An approach to the simulation of PCMs in building applications using TRNSYS,' Applied Thermal Eng., 25, 1796-1807, 2005.

[22] M. Koschenz, B. Lehmann, "Development of a thermally activated ceiling panel with PCM for application in lightweight and retrofitted buildings,' Energy Buildings, 36, 567-578, 2004.

[23] M. Ahmad, A. Bontemps, H. Sallée, D. Quenard, "Thermal testing and numerical simulation of a prototype cell using light wallboards coupling vacuum isolation panels and phase change material,', Energy Buildings, 38, 673-681, 2006.

[24] J. Miriel, L. Serres, A. Trombe, “Radiant ceiling panel heating-cooling systems: experimental and simulated study of the performances, thermal comfort and energy consumptions,' Applied Thermal Eng., 22, 1861-1873, 2002.

[25] H. Alireza, and K. Siddiqui. "Optimal design of a forced circulation solar water heating system for a residential unit in cold climate using TRNSYS." Solar Energy, 83, 700-714, 2009.

[26] University of Wisconsin--Madison. Solar Energy Laboratory, and Sanford A. Klein. TRNSYS, a transient system simulation program. Solar Energy Laborataory, University of Wisconsin--Madison, 1979. 